\title{
Bifunctional phase-transfer catalysis in the asymmetric synthesis of biologically active isoindolinones
}

\author{
Antonia Di Mola ${ }^{1,2}$, Maximilian Tiffner ${ }^{3}$, Francesco Scorzelli ${ }^{1}$, Laura Palombi ${ }^{1}$, \\ Rosanna Filosa ${ }^{4}$, Paolo De Caprariis ${ }^{2}$, Mario Waser ${ }^{\star} 3, \S$ and Antonio Massa ${ }^{*} 1, \pi$
}

\section{Full Research Paper}

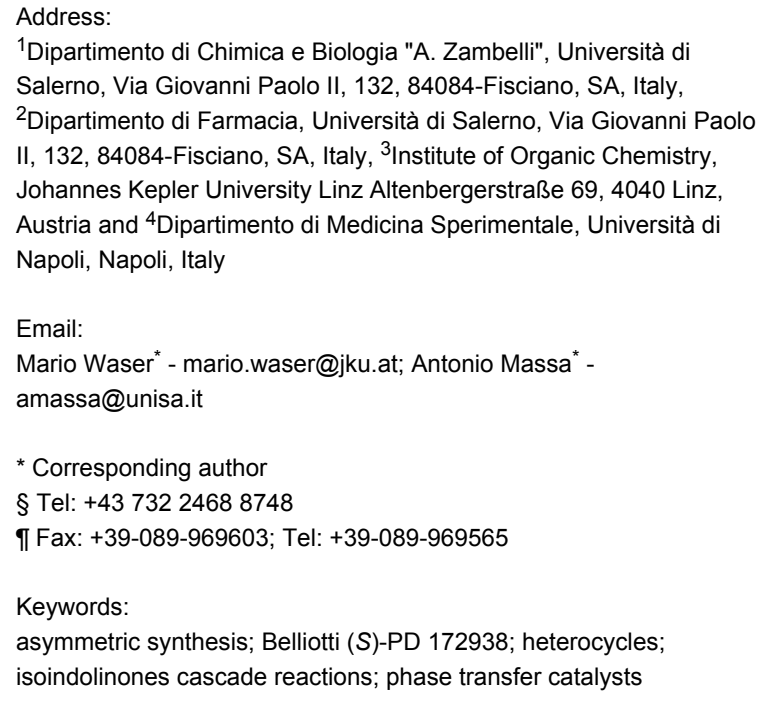

${ }^{1}$ Dipartimento di Chimica e Biologia "A. Zambelli", Università di Salerno, Via Giovanni Paolo II, 132, 84084-Fisciano, SA, Italy, 2Dipartimento di Farmacia, Università di Salerno, Via Giovanni Paolo II, 132, 84084-Fisciano, SA, Italy, ${ }^{3}$ Institute of Organic Chemistry, Johannes Kepler University Linz Altenbergerstraße 69, 4040 Linz, Austria and ${ }^{4}$ Dipartimento di Medicina Sperimentale, Università di Napoli, Napoli, Italy

\section{Email:}

Mario Waser ${ }^{*}$ - mario.waser@jku.at; Antonio Massa* amassa@unisa.it

* Corresponding author

§ Tel: +4373224688748

If Fax: +39-089-969603; Tel: +39-089-969565

Keywords:

asymmetric synthesis; Belliotti (S)-PD 172938; heterocycles;

isoindolinones cascade reactions; phase transfer catalysts

\author{
Beilstein J. Org. Chem. 2015, 11, 2591-2599. \\ doi:10.3762/bjoc.11.279
}

Received: 28 September 2015

Accepted: 02 December 2015

Published: 15 December 2015

This article is part of the Thematic Series "Bifunctional catalysis".

Guest Editor: D. Dixon

(c) 2015 Di Mola et al; licensee Beilstein-Institut.

License and terms: see end of document.

\begin{abstract}
New bifunctional chiral ammonium salts were investigated in an asymmetric cascade synthesis of a key building block for a variety of biologically relevant isoindolinones. With this chiral compound in hand, the development of further transformations allowed for the synthesis of diverse derivatives of high pharmaceutical value, such as the Belliotti (S)-PD172938 and arylated analogues with hypnotic sedative activity, obtained in good overall total yield (50\%) and high enantiomeric purity ( $95 \%$ ee). The synthetic routes developed herein are particularly convenient in comparison with the current methods available in literature and are particularly promising for large scale applications.
\end{abstract}

\section{Introduction}

Among the nitrogen heterocycles, the isoindolinone ring system is a favored scaffold, owing to the wide range of applications and pharmacological properties [1-3]. A relevant structural aspect is the presence of a substituent at the $\mathrm{C} 3$ position of the ring. A higher biological activity of the enantioenriched com- pounds with respect to racemic mixtures has been demonstrated for several 3-substituted isoindolinones, some of which are shown in Figure 1 [4-8]. For example, the enantioenriched isoindolinones $\mathbf{1}$ and $\mathbf{2}$ are benzodiazepine-receptor agonists for the treatment of anxiety [4-7]. Compound $(S)-3$, developed by 
Belliotti et al. and known as PD172938, is a potent dopamine $\mathrm{D}_{4}$ ligand [8] while hypnotic/sedative activity has been investigated only for rac-4 [6,7]. In the last years, the development of the efficient, catalytic, asymmetric synthesis of 3-substituted isoindolinones became a research field of great interest among organic and medicinal chemists [9-23]. Nevertheless, the enantioenriched compounds $\mathbf{1}-\mathbf{3}$ and their analogues have as of yet only been accessible via resolution approaches in less satisfactory overall yields (usually $<10 \%$ ). This is accompanied by the need of stoichiometric amounts of valuable chiral resolving agents, illustrating the need for more convenient strategies for large scale applications [4-8].

Recently, cascade reactions have received increasing attention due to the possibility of construction of complex scaffolds in operationally simple, one-pot procedures, starting from readily available materials [24-26]. In this context, our group recently introduced an interesting asymmetric organo-cascade reaction of 2-cyanobenzaldehyde (5) with malonate $\mathbf{6}$. This resulted in enantioenriched 2-(1-oxoisoindolin-3-yl)malonate 7 which is supposed to serve as a potentially useful building block for further elaborations en route to the targets of medicinal interest (Figure 1). A high yield (usually $>95 \%$ ) and a maximum level of enantioselectivity of $74 \%$ ee were obtained but only in the presence of large amounts of cinchona alkaloid-based thioureacontaining organocatalysts $(15 \mathrm{~mol} \%)$ and after an unacceptably long reaction time (72 h) $[21,22]$. Readily available chiral ammonium salts (e.g., cinchona alkaloid-based or commercially available Maruoka catalysts) were also investigated, but the enantioselectivity was lower, reaching a maximum of $46 \%$ ee [23]. Gratifyingly, a very efficient heterochiral crystallization (these isoindolinones crystallize as racemic mixtures) allowed the isolation of the product in high enantiomeric excesses ( $>90 \%$ ee) and good overall yield, making the entire process attractive from a synthetic point of view [21,23]. However, several issues remain to be addressed when targeting the use of such a catalytic strategy to access the target compounds $\mathbf{1}-\mathbf{4}$ in an efficient manner.

The availability of efficient catalytic processes is a fundamental requirement for the development of scalable synthetic routes of bioactive compounds. Thus, in the present work, we firstly reconsidered this cascade reaction, investigating novel trans1,2-cyclohexane diamine-based bifunctional ammonium salts $\mathbf{8}$. These catalysts were recently introduced by our groups in a variety of different reactions [27-29], as exemplified by a related aldol-initiated cascade reaction of glycine Schiff base with 2-cyanobenzaldehydes [29]. Then we decided to address the asymmetric synthesis of bioactive isoindolinones, identifying the chiral isoindolinone $\mathbf{9}$ as a very useful, key building block, as shown in Scheme 1.

\section{Results and Discussion Asymmetric cascade reaction of 2-cyano- benzaldehyde under phase-transfer conditions}

As already discussed [21-23], the bifunctional nature of organocatalysts plays an important role in this reaction to attain satisfactory levels of enantioselectivity. The presence of additional hydrogen donors such as urea groups positively affected the enantioselectivity both in the presence of chiral base organo-catalysts and when using quaternary ammonium salts. In the latter case, however, only $46 \%$ ee was obtained using the bifunctional urea-containing ammonium salt catalyst introduced by Dixon's group [30]. Readily available commonly used quaternary ammonium salt catalysts gave racemic mixtures only, although high reactivity was generally observed [23].

Taking advantage of the high flexibility and efficiency of the developed synthetic route to 8 [27,29], a library of more than 20 structurally diversified chiral ammonium salts was tested in the

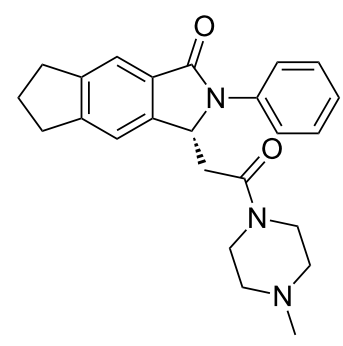

1: JM 1232

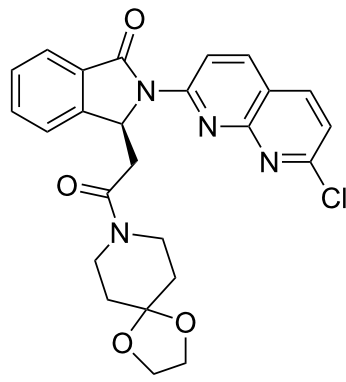

2: pazinaclone<smiles>Cc1ccc(N2CCN(CC[C@H]3NC(=O)c4ccccc43)CC2)cc1C</smiles>

3: PD172938 


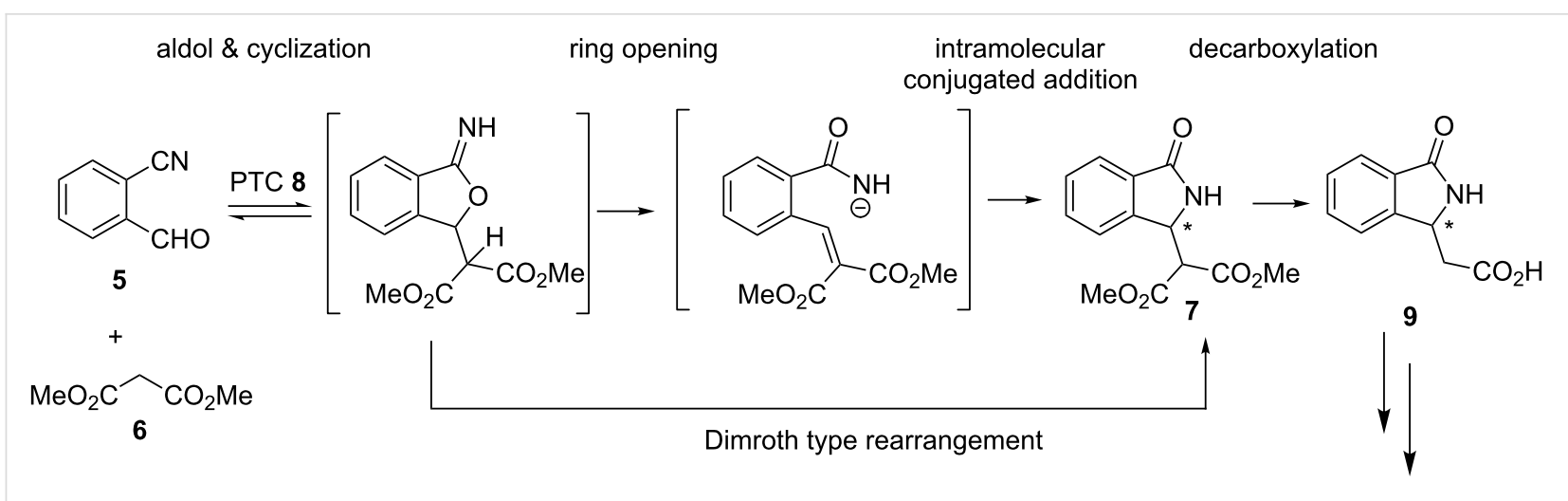

bioactive isoindolinones

Scheme 1: This work: 1) trans-1,2-cyclohexane diamine-based bifunctional ammonium salts 8 in the asymmetric synthesis of 7 ; 2 ) transformation of 7 into 9 ; 3 ) asymmetric synthesis of bioactive isoindolinones.

Table 1: Catalyst screening in asymmetric cascade reactions of 2-cyanobenzaldehyde.

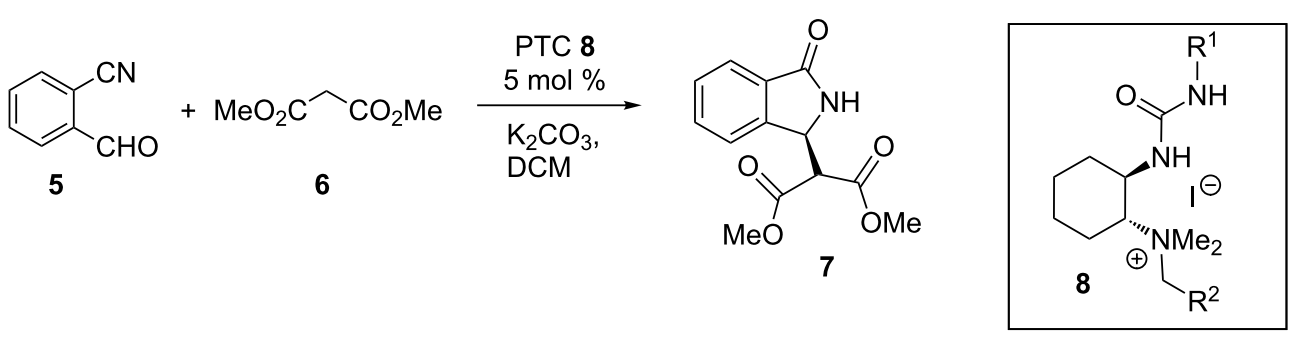

\begin{tabular}{|c|c|c|c|c|}
\hline Entry & $\mathrm{R}^{1}$ & $\mathrm{R}^{2}$ & Yield (\%) ${ }^{a}$ & $e e^{b}$ \\
\hline 1 & $\mathrm{Ph}$ & $\mathrm{H}$ & 96 & 4 \\
\hline 2 & $\mathrm{Ph}$ & $\mathrm{Ph}$ & 92 & 22 \\
\hline 3 & $\mathrm{Ph}$ & $\beta-N p$ & 91 & 20 \\
\hline 4 & $\mathrm{Ph}$ & $4-t-\mathrm{Bu}-\mathrm{C}_{6} \mathrm{H}_{4}$ & 83 & 6 \\
\hline 5 & $\mathrm{Ph}$ & $3,5-\mathrm{F}_{2}-4-\mathrm{OMe}-\mathrm{C}_{6} \mathrm{H}_{2}$ & 92 & 26 \\
\hline 6 & $\mathrm{Ph}$ & $\alpha-N p$ & 95 & 24 \\
\hline 7 & $\mathrm{Ph}$ & $3-\mathrm{NO}_{2}-\mathrm{C}_{6} \mathrm{H}_{4}$ & 94 & 32 \\
\hline 8 & $3-\mathrm{NO}_{2}-\mathrm{C}_{6} \mathrm{H}_{4}$ & $4-\mathrm{Br}-\mathrm{C}_{6} \mathrm{H}_{4}$ & 95 & 38 \\
\hline 9 & Cy & $3,5-\left(\mathrm{CF}_{3}\right)_{2}-\mathrm{C}_{6} \mathrm{H}_{3}$ & 91 & 28 \\
\hline 10 & Et & $3,5-\left(\mathrm{CF}_{3}\right)_{2}-\mathrm{C}_{6} \mathrm{H}_{3}$ & 94 & 28 \\
\hline 11 & $3-\mathrm{NO}_{2}-\mathrm{C}_{6} \mathrm{H}_{4}$ & $\mathrm{Ph}$ & 92 & 32 \\
\hline $12^{c}$ & $3-\mathrm{NO}_{2}-\mathrm{C}_{6} \mathrm{H}_{4}$ & $\mathrm{Ph}$ & 95 & 26 \\
\hline 13 & $3-\mathrm{NO}_{2}-\mathrm{C}_{6} \mathrm{H}_{4}$ & $3,5-\mathrm{F}_{2}-4-\mathrm{OMe}-\mathrm{C}_{6} \mathrm{H}_{2}$ & 94 & 40 \\
\hline 14 & $3-\mathrm{NO}_{2}-\mathrm{C}_{6} \mathrm{H}_{4}$ & $4-t-B u-C_{6} \mathrm{H}_{4}$ & 92 & 30 \\
\hline 15 & $3-\mathrm{NO}_{2}-\mathrm{C}_{6} \mathrm{H}_{4}$ & $\beta-\mathrm{Np}$ & 95 & 34 \\
\hline 16 & $3-\mathrm{NO}_{2}-\mathrm{C}_{6} \mathrm{H}_{4}$ & $3,5-\left(\mathrm{CF}_{3}\right)_{2}-\mathrm{C}_{6} \mathrm{H}_{3}$ & 96 & 66 \\
\hline 17 & $4-\mathrm{NO}_{2}-\mathrm{C}_{6} \mathrm{H}_{4}$ & $3,5-\left(\mathrm{CF}_{3}\right)_{2}-\mathrm{C}_{6} \mathrm{H}_{3}$ & 95 & 70 \\
\hline 18 & $(R)-\mathrm{PhCHCH}_{3}$ & $3,5-\left(\mathrm{CF}_{3}\right)_{2}-\mathrm{C}_{6} \mathrm{H}_{3}$ & 94 & 30 \\
\hline 19 & $(S)-\mathrm{PhCHCH}_{3}$ & $3,5-\left(\mathrm{CF}_{3}\right)_{2}-\mathrm{C}_{6} \mathrm{H}_{3}$ & 96 & 28 \\
\hline 20 & $2-\mathrm{Cl}-5-\mathrm{NO}_{2}-\mathrm{C}_{6} \mathrm{H}_{3}$ & $3,5-\left(\mathrm{CF}_{3}\right)_{2}-\mathrm{C}_{6} \mathrm{H}_{3}$ & 96 & 62 \\
\hline 21 & $3,5-\left(\mathrm{CF}_{3}\right)_{2}-\mathrm{C}_{6} \mathrm{H}_{3}$ & $3,5-\left(\mathrm{CF}_{3}\right)_{2}-\mathrm{C}_{6} \mathrm{H}_{3}$ & 96 & 64 \\
\hline 22 & $3,5-\left(\mathrm{CO}_{2} \mathrm{Me}\right)_{2}-\mathrm{C}_{6} \mathrm{H}_{3}$ & $3,5-\left(\mathrm{CF}_{3}\right)_{2}-\mathrm{C}_{6} \mathrm{H}_{3}$ & 95 & 55 \\
\hline 23 & $4-\mathrm{CF}_{3}-\mathrm{C}_{6} \mathrm{H}_{3}$ & $3,5-\left(\mathrm{CF}_{3}\right)_{2}-\mathrm{C}_{6} \mathrm{H}_{3}$ & 96 & 60 \\
\hline
\end{tabular}

alsolated yields after $15 \mathrm{~h}$ reaction time using $5 \mathrm{~mol} \%$ of the catalysts. ${ }^{\mathrm{b}}$ Determined by HPLC on chiral stationary phase. ${ }^{\mathrm{c}}$ The thiourea was tested. 
model cascade reaction of 2-cyanobenzaldehyde with dimethyl malonate at room temperature (Table 1). We first identified the combination of DCM and solid $\mathrm{K}_{2} \mathrm{CO}_{3}$ as the best-suited solvent-base system for this reaction, however etheral or aromatic solvents or aqueous (alternative) bases generally gave significantly lower selectivities (this was carefully doublechecked once the most active catalyst was identified). High yields were usually observed $(>90 \%)$ when running the reaction for one night using $5 \mathrm{~mol} \%$ of the catalyst. Good levels of enantioselectivity (up to $70 \%$ ee) were obtained when strong electron-withdrawing groups are present on both the urea and ammonium sides of the catalyst (Table 1, entries 16, 17, and 21). Electron-neutral or bulky aryl groups on the ammonium side, as well as the introduction of a naphthyl group, did not result in any improvement of the enantioselectivity. Also, the presence of aliphatic groups on the urea side did not allow us to improve the catalyst performance and a similar selectivity was obtained upon incorporation of more electron-rich aryl groups $\mathrm{R}^{1}$. The initial tests also showed that ureas are more selective than thioureas (Table 1, entry 12). Thus further optimization was carried out with ureas only, finally identifying the catalyst 8a $\left(\mathrm{R}^{1}=4-\mathrm{NO}_{2}-\mathrm{C}_{6} \mathrm{H}_{4}, \mathrm{R}^{2}=3,5-\left(\mathrm{CF}_{3}\right)_{2}-\mathrm{C}_{6} \mathrm{H}_{3}\right)$ as the most promising one (Table 1 , entry 17). It should also be noted that control experiments with catalyst derivatives containing only either a quaternary ammonium or a urea group proved the need for both of these functionalities to obtain satisfactory levels of enantioselectivity.

As mentioned before, the combination of solid $\mathrm{K}_{2} \mathrm{CO}_{3}$ as the base and DCM as the solvent was identified as the best system for this reaction and other reaction parameters (catalyst and base amounts, temperature, molar concentration) were systematically investigated next. Table 2 summarizes the most relevant results. Base amounts of $0.25-1$ equiv (with respect to aldehyde 5) can be used without affecting the enantioselectivity, but this results in a slightly reduced reaction rate when using less base. By varying the temperature, dilution, and catalyst loading, as shown in Table 2, 7 was finally obtained with $78 \%$ ee and in almost quantitative yield with a reasonably short reaction time when using only $2.5 \mathrm{~mol} \%$ of the catalyst at $-10{ }^{\circ} \mathrm{C}$ (Table 2, entry 9). Keeping in mind the fact that significantly larger amounts of catalyst and much longer reaction times were required to achieve a somewhat comparable selectivity and yield with organocatalysts found in the literature [2123 ], these results encouraged us to use this methodology to access larger quantities of $\mathbf{8}$ next.

Thus, under the conditions of entry 9 in Table 2, the reaction was successfully scaled up to a practical $2 \mathrm{mmol}$ scale with unchanged efficiency. After crystallization, we were able to obtain reasonable quantities of $(S)-7$ with $95 \%$ ee and an overall yield of $77 \%$. The availability of both the enantiomers of the catalysts is another important advantage because of the possibility to obtain both the enantiomers of chiral bioactive compounds. In this case, we focused on $(R, R)-\mathbf{8 a}$, which afforded the required $(S)-7$ (the absolute configuration has been previously determined by vibrational circular dichroism) [31].

\section{Asymmetric synthesis of 9 by decarboxyla- tion of (S)-7}

Although several methods to obtain rac-9 are available [32-36], it is worth noting that the asymmetric synthesis of 9 is one of the major obstacles when targeting the synthesis of chiral isoindolinones. The recently introduced intramolecular aza-Michael reactions of 2-substituted acrylates gave very poor enantioselectivity (ee $<10 \%$ ) [9], while racemic analogues of 9 were resolved in the past in very low yields [4]. This disappointing picture prompted us to find a viable access route to enantioenriched 9. We thus investigated the decarboxylation of the chiral dimethyl 2-(S)-(1-oxoisoindolin-3-yl)malonate ((S)-7), according to Scheme 2. We firstly focused on two well-known mild procedures in order to avoid the classical harsh acidic

\begin{tabular}{|c|c|c|c|c|c|c|}
\hline Entry & $\begin{array}{l}\text { Catalyst 8a } \\
\text { mol \% }\end{array}$ & $T\left({ }^{\circ} \mathrm{C}\right)$ & {$[5]^{a}$} & Time $(\mathrm{h})$ & Yield $(\%)^{b}$ & $e e^{c}$ \\
\hline 1 & $5 \mathrm{~mol} \%$ & $\mathrm{rt}$ & 0.033 & 15 & 95 & 70 \\
\hline 2 & $5 \mathrm{~mol} \%$ & $0^{\circ} \mathrm{C}$ & 0.033 & 15 & 95 & 75 \\
\hline 3 & $5 \mathrm{~mol} \%$ & $-10^{\circ} \mathrm{C}$ & 0.033 & 15 & 95 & 76 \\
\hline 4 & $5 \mathrm{~mol} \%$ & $-20^{\circ} \mathrm{C}$ & 0.033 & 15 & 95 & 60 \\
\hline 5 & $5 \mathrm{~mol} \%$ & $0^{\circ} \mathrm{C}$ & 0.067 & 6 & 92 & 73 \\
\hline 6 & $5 \mathrm{~mol} \%$ & $0^{\circ} \mathrm{C}$ & 0.017 & 15 & 91 & 64 \\
\hline 7 & $10 \mathrm{~mol} \%$ & $\mathrm{rt}$ & 0.017 & 15 & 94 & 72 \\
\hline 8 & $2.5 \mathrm{~mol} \%$ & $0^{\circ} \mathrm{C}$ & 0.067 & 6 & 93 & 73 \\
\hline 9 & $2.5 \mathrm{~mol} \%$ & $-10^{\circ} \mathrm{C}$ & 0.067 & 10 & 98 & 78 \\
\hline
\end{tabular}

aAldehyde molar concentration. ${ }^{b}$ Isolated yields. 'Determined by HPLC on chiral stationary phase. 


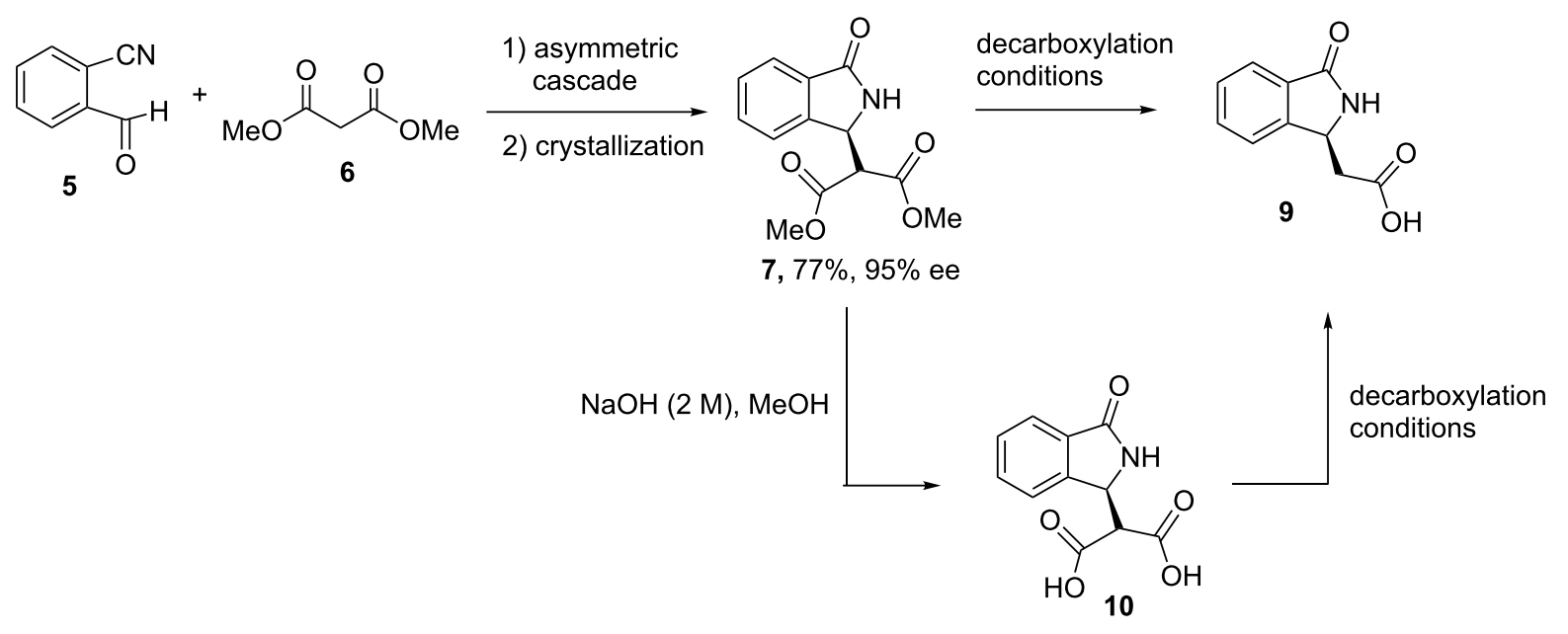

Scheme 2: Asymmetric cascade, crystallization and decarboxylation reaction.

conditions. Disappointingly, modifications of the Krapcho decarboxylation performed with a $\mathrm{LiCl} / \mathrm{H}_{2} \mathrm{O} / \mathrm{DMF}$ mixture under reflux [36,37] led to partial racemization of the recovered methyl ester of 9 (60\% ee), although high yields were observed (Table 3, entry 1). Then, in another attempt, the malonic acid 10 was subjected to the reaction with carbonyldiimidazole (CDI) under different conditions but also in combination with a piperazine. This method has been reported for a number of malonic acids [38] to afford the respective monoacid or directly the mono-amide derivative when the decarboxylation is performed in the presence of amines. However, we were not able to isolate the target compounds since we observed very low conversions and decomposition products. Therefore, we focused on the classical procedures carried out under acidic conditions. Luckily, the decarboxylation of both diester 7 and diacid 10 was particularly encouraging when performed in $6 \mathrm{M}$ $\mathrm{HCl}$ solution at reflux in a very short reaction time. This gave the chiral acid 9 in high yield with essentially no loss in ee (Table 3, entries 4 and 8).

On the other hand, partial racemization was detected at longer reaction times (Table 3, entries 2, 3 and 7). This somewhat matched the time-dependent loss in ee observed by Allin et al. in the $\mathrm{N}$-deprotection with $\mathrm{H}_{2} \mathrm{SO}_{4}$ of other chiral 3-substituted isoindolinones [39]. The racemization probably occurs on the product 9, via the mechanism reported in Scheme 3, as a slower process than the decarboxylation itself. The cleavage of the $\mathrm{C}-\mathrm{N}$ bond and the formation of the acyclic intermediates $\mathbf{1 1}$ with the consequent loss of chirality is probably favored by the protonation of the $\mathrm{C}=\mathrm{O}$ group of the lactam. A similar retroMichael racemization mechanism can be envisioned for the Krapcho decarboxylation, in which the Lewis acid $\mathrm{Li}^{+}$can coordinate the lactam group. In principle, racemization could also occur on 7 . However, under the optimized conditions, the decar-

Table 3: Optimization of the decarboxylation reaction.

\begin{tabular}{|c|c|c|c|c|c|c|}
\hline Entry & Conditions & Substrate & $T\left({ }^{\circ} \mathrm{C}\right)$ & Time & Yield $(\%)^{a}$ & $e e^{b}$ \\
\hline $1^{c}$ & Krapcho decarboxylation & 7 & reflux & $2 \mathrm{~h}$ & 85 & $60(37)^{\mathrm{d}}$ \\
\hline 2 & $\mathrm{HCl} 6 \mathrm{~N}$ & 7 & 60 & $96 \mathrm{~h}$ & 51 & $36(60)^{d}$ \\
\hline 3 & $\mathrm{HCl} 6 \mathrm{~N}$ & 7 & reflux & $1 \mathrm{~h}$ & 96 & $91(3)^{d}$ \\
\hline 4 & $\mathrm{HCl} 6 \mathrm{~N}$ & 7 & reflux & $30 \min$ & 90 & $95(0)^{d}$ \\
\hline 5 & $\mathrm{CDI} / \mathrm{NaOH}$ & 10 & rt & $24 \mathrm{~h}$ & - & - \\
\hline 6 & $\mathrm{HCl} 3 \mathrm{M}$ & 10 & 50 & $24 \mathrm{~h}$ & - & - \\
\hline 7 & $\mathrm{HCl} 1 \mathrm{M}$ & 10 & 80 & $3 \mathrm{~h}$ & 46 & $85(10)^{d}$ \\
\hline 8 & $\mathrm{HCl} 6 \mathrm{M}$ & 10 & reflux & $15 \min$ & 97 & $95(0)^{d}$ \\
\hline
\end{tabular}

alsolated yield. ${ }^{b}$ Determined by HPLC on chiral column on methyl ester. ${ }^{\mathrm{c}}$ The methyl ester of $\mathbf{9}$ was obtained. ${ }^{\mathrm{d}} \Delta \mathrm{ee}=\mathrm{ee}_{\mathbf{5}}-\mathrm{ee}_{\mathbf{6}}$. 
<smiles>O=C(O)CC1NC(=O)c2ccccc21</smiles><smiles>C=CC1NC(=O)c2ccccc2[C@H]1C(=O)O</smiles><smiles>C#CC#CC(=O)O</smiles>

Scheme 3: Proposed racemization pathways of isoindolinones 9 via retro-Michael process.

boxylation is a faster process and $\mathbf{7}$ or $\mathbf{1 0}$ have never been recovered. Since the decarboxylation does not directly affect the stereocenter, we can confidently assign the absolute configuration of (-)-9 as $(S)$.

\section{Asymmetric synthesis of bioactive isoin- dolinones}

Inspired by well-known synthetic routes of racemic derivatives $[4,5,8,36],(S)-9$ was found to be particularly useful in the asymmetric synthesis of a series of chiral intermediates and bioactive isoindolinones. Firstly, we focused on the reduction of methyl ester 12 to give the chiral alcohol 13. In this case, $\mathrm{LiBH}_{4}$ was particularly effective, leading to $13 \mathrm{in}$ high yield, and most importantly, without a reduction in ee value. To our knowledge, this is the first asymmetric synthesis of $\mathbf{1 3}$. On the other hand, $\mathrm{NaBH}_{4}$, previously employed by Belliotti [8] for the reduction of $r a c-12$, gave less satisfactory results. Then $\mathbf{1 3}$ was subjected to reaction with mesyl chloride and the subsequent displace- ment with 1-(3,4-(dimethylphenyl)pyperazine (15) gave $\mathbf{3}$, the potent dopamine $\mathrm{D}_{4}$ ligand $(S)$-PD172938, in high overall yield (51\%), with $95 \%$ ee (Scheme 4).

Then, the amide 16, which is of particular interest in the field of benzodiazepine-receptor agonists, was efficiently obtained by condensation of the chiral acid $(S)-9$ with the commercially available piperazine 16. Since most of the bioactive isoindolinones have a heteroaromatic group on the lactam, we focused on the $\mathrm{CuI}$ arylation of amides developed by Buchwald [40], previously applied by us to racemic derivatives [36]. Thus, we reacted the two model chiral isoindolinones $\mathbf{1 2}$ and $\mathbf{1 7}$ (bearing an ester and amide moiety in the side chains, respectively) with two different 2-iodopyridines 18 and 19. This was done in the presence of $\mathrm{CuI}$ and $N, N$-dimethylethylenediamine (20) as the ligand in dioxane, improving the previous version developed on the racemates (Scheme 5) [36]. This method also allowed us to obtain the analogues $\mathbf{2 1}$ and $\mathbf{2 2}$ of the bioactive<smiles>O=C(O)CC1NC(=O)c2ccccc21</smiles><smiles>COC(=O)C(C)OC</smiles>
9, $95 \%$<smiles>COC(=O)CC1NC(=O)c2ccccc21</smiles>

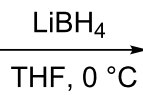

TEA, 15

$\mathrm{CH}_{2} \mathrm{Cl}_{2}, 50^{\circ} \mathrm{C}$<smiles>CC(C)(C)OCCC1NC(=O)c2ccccc21</smiles>

$\mathrm{MsCl}$ TEA<smiles>CCC1NC(=O)c2ccccc21</smiles>

3: $87 \%, 95 \%$ ee (S)-PD172938 


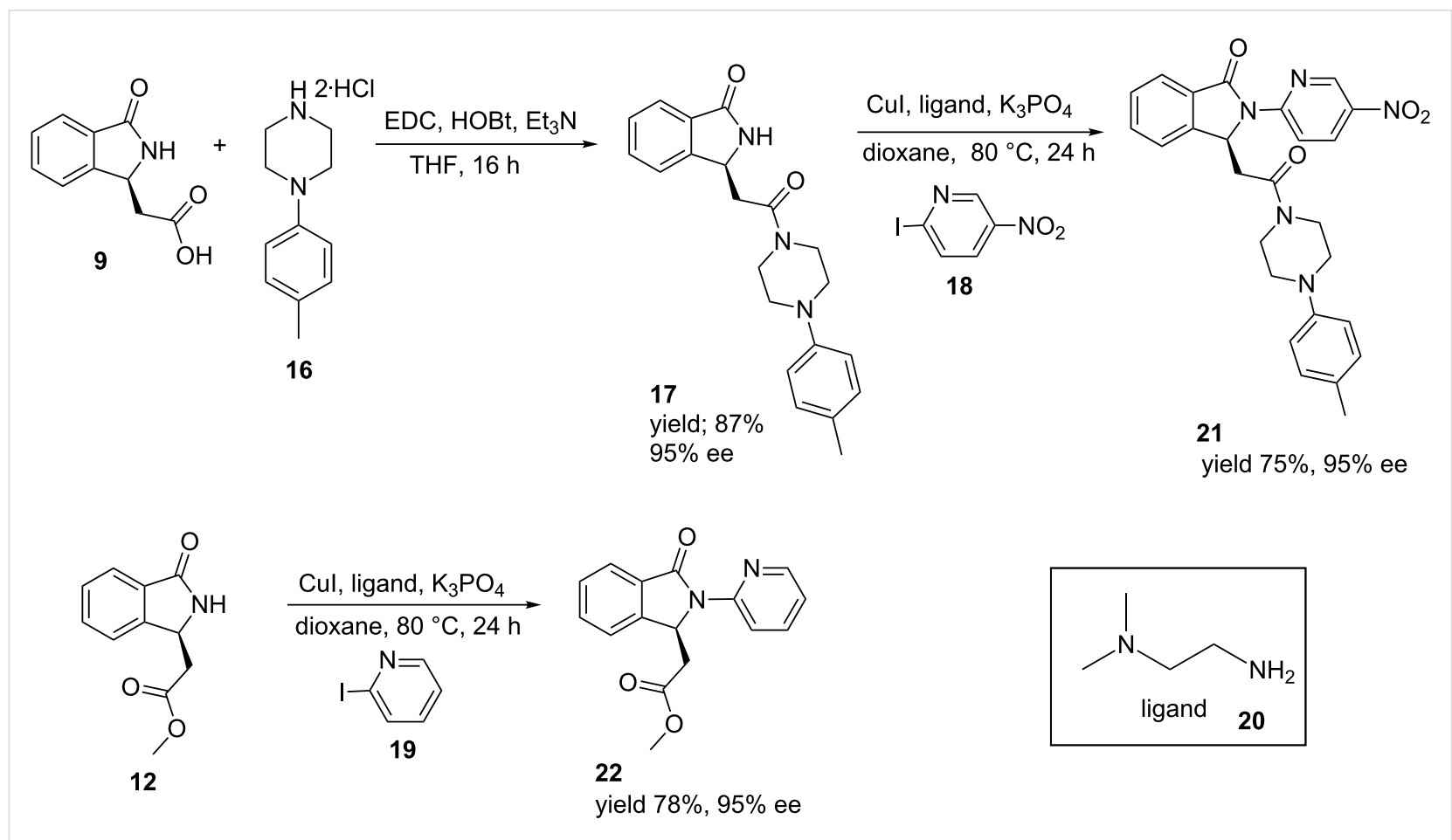

Scheme 5: Coupling of chiral acid 9 with p-tolylpiperazine and Cul arylation of chiral isoindolinones.

isoindolinones described in Figure 1 in high overall yield (50\%) without loss in enantiomeric purity.

\section{Conclusion}

Recently developed $(R, R)$-1,2-cyclohexanediamine-based bifunctional ammonium salts were investigated in the cascade reaction of 2-cyanobenzaldehyde with dimethyl malonate for the synthesis of $(S)$-2-(1-oxoisoindolin-3-yl)malonate. Very high yields and good enantioselectivities were obtained with only $2.5 \mathrm{~mol} \%$ of the catalyst, improving previous versions performed in the presence of bifunctional organocatalysts and other readily available ammonium salts. Then, decarboxylation of this compound and further transformations allowed the synthesis of the Belliotti (S)-PD172938 and of other derivatives with diverse biological activities, in about $50 \%$ overall yield with $95 \%$ ee. Since the developed routes are particularly convenient in comparison to other syntheses reported in literature, further optimization and the synthesis of other bioactive isoindolinones are ongoing in our laboratory.

\section{Experimental}

(S)-Dimethyl 2-(1-oxoisoindolin-3-yl)malonate (7). A mixture of 2-cyanobenzaldehyde 5 (262 $\mathrm{mg}, 2 \mathrm{mmol}), \mathrm{K}_{2} \mathrm{CO}_{3}$ $(276 \mathrm{mg}, 2 \mathrm{mmol})$ and $(R, R)$-catalyst $8 \mathbf{a}(27 \mathrm{mg}, 0.05 \mathrm{mmol}$, $2.5 \mathrm{~mol} \%)$ was dissolved in dichloromethane $(30 \mathrm{~mL}, 0.066 \mathrm{M})$ and cooled to $-10{ }^{\circ} \mathrm{C}$ while stirring. Within a period of $2 \mathrm{~min}$, dimethyl malonate 6 (245 $\mu \mathrm{L}, 2.4$ mmol, 1.2 equiv) was added.
After $10 \mathrm{~h}$ (reaction monitored by TLC), the reaction mixture was filtered through a plug of $\mathrm{Na}_{2} \mathrm{SO}_{4}$. The solvent was removed under reduced pressure. The crude product was purified by column chromatography (silica gel, heptanes/ethyl acetate 1:1) giving the product as a colorless oil in $98 \%$ yield (520 mg, $1.96 \mathrm{mmol}$ ) and ee 78\%. The enantiomers were separated by HPCL using the following conditions: Chiralcel AD-H, $n$-hexane/iPrOH 70:30, $1.0 \mathrm{~mL} / \mathrm{min}, 10^{\circ} \mathrm{C}, 12.3 \mathrm{~min}$ (minor; $R$-enantiomer), $25.5 \mathrm{~min}$ (major; $S$-enantiomer). The product was dissolved in a mixture of dichloromethane $(6 \mathrm{~mL})$ and heptanes $(4 \mathrm{~mL})$ and after crystallization overnight at $-20{ }^{\circ} \mathrm{C}$, the solid was filtered off and the solution containing the enantioenriched compound was evaporated and analyzed by chiral HPLC. The resulting enantioenriched product was obtained as a colourless oil in $77 \%$ overall yield $(400 \mathrm{mg}$, $1.51 \mathrm{mmol}, 95 \%$ ee). The spectroscopic data are in agreement with that reported in literature $[21,22]$. Chiralpack AD column, hexane/iPrOH $8: 2,0.8 \mathrm{~mL} / \mathrm{min}, \lambda=254 \mathrm{~nm}, t=19.4 \mathrm{~min}$, $t=29.3 \mathrm{~min}$.

(S)-2-(1-Oxoisoindolin-3-yl)acetic acid (9) from 7. A flask containing a solution of isoindolinone $7(320 \mathrm{mg}, 1.20 \mathrm{mmol})$ and $\mathrm{HCl} 6 \mathrm{M}(2 \mathrm{~mL})$ was immersed in a preheated oil bath and refluxed for $30 \mathrm{~min}$. The mixture was extracted with ethyl acetate $(3 \times 15 \mathrm{~mL})$. The combined organic layers were dried $\left(\mathrm{MgSO}_{4}\right)$, and the solvent was evaporated to give compound $\mathbf{9}$, which was purified with silica gel using ethyl acetate. Com- 
pound 9 was obtained as a white solid $(208 \mathrm{mg}, 1.09 \mathrm{mmol}$, 90\%). Mp 170-171 ${ }^{\circ} \mathrm{C}$ (from ethyl acetate); ESIMS $(\mathrm{m} / \mathrm{z})$ : $190.18(\mathrm{M}-\mathrm{H})^{-} ;[\alpha]_{\mathrm{D}}{ }^{22}-21$ (c 1.0, methanol); Anal. calcd for $\mathrm{C}_{10} \mathrm{H}_{9} \mathrm{NO}_{3}$ : C, 62.82; H, 4.74; N, 7.33; found: $\mathrm{C}, 62.72 ; \mathrm{H}$, $4.78 ; \mathrm{N}, 7.01 ;{ }^{1} \mathrm{H}$ NMR $\left(300 \mathrm{MHz}, \mathrm{CD}_{3} \mathrm{OD}\right) 7.76$ (d, $J=7.5$ $\mathrm{Hz}, 1 \mathrm{H}), 7.65-7.53(\mathrm{~m}, 2 \mathrm{H}), 7.51-7.48(\mathrm{~m}, 1 \mathrm{H}), 5.09-4.99(\mathrm{~m}$, $1 \mathrm{H}), 2.97-2.89(\mathrm{~m}, 1 \mathrm{H}), 2.68-2.48(\mathrm{~m}, 1 \mathrm{H}) ;{ }^{13} \mathrm{C} \mathrm{NMR}$ (100 MHz, $\left.\mathrm{CD}_{3} \mathrm{OD}\right) \delta 172.6,171.2,146.8,131.9,131.3,128.1$, $122.9,122.6,53.4,38.3$. The enantiomeric excess was determined by derivatization of the compound into methyl ester 12 or amide $\mathbf{1 6}$.

\section{Supporting Information}

\section{Supporting Information File 1}

Complete experimental details and procedures, spectroscopic data, copies of ${ }^{1} \mathrm{H}$ NMR, ${ }^{13} \mathrm{C}$ NMR and HPLC traces.

[http://www.beilstein-journals.org/bjoc/content/ supplementary/1860-5397-11-279-S1.pdf]

\section{Acknowledgements}

This work was supported by the MIUR, University of Salerno and the Austrian Science Funds (FWF): Project No. P26387N28.

\section{References}

1. Speck, K.; Magauer, T. Beilstein J. Org. Chem. 2013, 9, 2048-2078. doi:10.3762/bjoc.9.243

2. Di Mola, A.; Palombi, L.; Massa, A. Curr. Org. Chem. 2012, 16, 2302-2320. doi:10.2174/138527212803520254

3. Di Mola, A.; Palombi, L.; Massa, A. An overview on asymmetric synthesis of 3-substituted indolinones. In Targets in Heterocyclic Systems: Chemistry and Properties; Attanasi, O. A.; Noto, R.; Spinelli, D., Eds.; Italian Society of Chemistry: Rome, 2014; Vol. 18, pp 113-140.

See for a review on asymmetric synthesis of isoindolinones.

4. Kanamitsu, N.; Osaki, T.; Itsuji, Y.; Yoshimura, M.; Tsujimoto, H.; Soga, M. Chem. Pharm. Bull. 2007, 55, 1682-1688. doi:10.1248/cpb.55.1682

5. Toyooka, K.; Kanamitsu, N.; Yoshimura, M.; Kuriyama, K. S.; Tamura, H.; Takashi, K. S. Isoindoline derivatives. PCT Patent PCT/JP2003/014986, 2003.

6. Hussein, Z.; Mulford, D. J.; Bopp, B. A.; Granneman, G. R. Br. J. Clin. Pharmacol. 1993, 36, 357-361. doi:10.1111/j.1365-2125.1993.tb00376.x

7. Kondo, T.; Yoshida, K.; Yamamoto, M.; Tanayama, S. Arzneim. Forsch. 1996, 46, 11-14.

8. Belliotti, T. R.; Brink, W. A.; Kesten, S. R.; Rubin, J. R.; Wustrow, D. J.; Zoski, K. T.; Whetzel, S. Z.; Corbin, A. E.; Pugsley, T. A.; Heffner, T. G.; Wise, L. D. Bioorg. Med. Chem. Lett. 1998, 8, 1499-1502. doi:10.1016/S0960-894X(98)00252-2
9. Lebrun, S.; Sallio, R.; Dubois, M.; Agbossou-Niedercorn, F.; Deniau, E.; Michon, C. Eur. J. Org. Chem. 2015, 1995-2004. doi:10.1002/ejoc.201403573

10. Bisai, V.; Unhale, R. A.; Suneja, A.; Dhanasekaran, S.; Singh, V. K. Org. Lett. 2015, 17, 2102-2105. doi:10.1021/acs.orglett.5b00676

11. Li, T.; Zhou, S.; Wang, J.; Aceña, J. L.; Soloshonok, V. A.; Liu, H. Chem. Commun. 2015, 51, 1624-1626. doi:10.1039/C4CC05659K

12. Scorzelli, F.; Di Mola, A.; Palombi, L.; Massa, A. Molecules 2015, 20 , 8484-8498. doi:10.3390/molecules20058484

13. Nishimura, T.; Noishiki, A.; Ebe, Y.; Hayashi, T. Angew. Chem., Int. Ed. 2013, 52, 1777-1780. doi:10.1002/anie.201208593

14.Zhou, J.-Q.; Sheng, W.-J.; Jia, J.-H.; Ye, Q.; Gao, J.-R.; Jia, Y.-X. Tetrahedron Lett. 2013, 54, 3082-3084. doi:10.1016/j.tetlet.2013.03.138

15. Yang, G.; Shen, C.; Zhang, W. Angew. Chem., Int. Ed. 2012, 51, 9141-9145. doi:10.1002/anie.201203693

16. Chen, M.-W.; Chen, Q.-A.; Duan, Y.; Ye, Z.-S.; Zhou, Y.-G. Chem. Commun. 2012, 48, 1698-1700. doi:10.1039/C2CC16832D

17. Fujioka, M.; Morimoto, T.; Tsumagari, T.; Tanimoto, H.; Nishiyama, Y.; Kakiuchi, K. J. Org. Chem. 2012, 77, 2911-2923. doi:10.1021/jo300201g

18. Yu, X.; Wang, Y.; Wu, G.; Song, H.; Zhou, Z.; Tang, C. Eur. J. Org. Chem. 2011, 3060-3066. doi:10.1002/ejoc.201100163

19. Guo, S.; Xie, Y.; Hu, X.; Xia, C.; Huang, H. Angew. Chem., Int. Ed. 2010, 49, 2728-2731. doi:10.1002/anie.200907320

20. Wang, Z.-Q.; Feng, C.-G.; Xu, M.-H.; Lin, G.-Q. J. Am. Chem. Soc. 2007, 129, 5336-5337. doi:10.1021/ja0710914

21. More, V.; Rohlmann, R.; García Mancheño, O.; Petronzi, C.; Palombi, L.; De Rosa, A.; Di Mola, A.; Massa, A. RSC Adv. 2012, 2 , 3592-3595. doi:10.1039/C2RA20231J

22. Tiso, S.; Palombi, L.; Vignes, C.; Di Mola, A.; Massa, A. RSC Adv. 2013, 3, 19380-19387. doi:10.1039/C3RA43074J

23. Tiso, S.; Massa, A. J. Heterocycl. Chem. 2015, 52, 1570-1575. doi:10.1002/jhet.2170

24. Vetica, F.; de Figueiredo, R. M.; Orsini, M.; Tofani, D.; Gasperi, T. Synthesis 2015, 47, 2139-2184. doi:10.1055/s-0034-1378742

25. Wang, Y.; Lu, H.; Xu, P.-F. Acc. Chem. Res. 2015, 48, 1832-1844. doi:10.1021/acs.accounts.5b00217

26. Chauhan, P.; Mahajan, S.; Kaya, U.; Hack, D.; Enders, D. Adv. Synth. Catal. 2015, 357, 253-281. doi:10.1002/adsc.201401003

27. Novacek, J.; Waser, M. Eur. J. Org. Chem. 2014, 802-809. doi:10.1002/ejoc.201301594

28. Perillo, M.; Di Mola, A.; Filosa, R.; Palombi, L.; Massa, A. RSC Adv. 2014, 4, 4239-4246. doi:10.1039/C3RA46268D

29. Tiffner, M.; Novacek, J.; Busillo, A.; Gratzer, K.; Massa, A.; Waser, M. RSC Adv. 2015, 5, 78941-78949. doi:10.1039/C5RA14466C

30. Johnson, K. M.; Rattley, M. S.; Sladojevich, F.; Barber, D. M.; Nuñez, M. G.; Goldys, A. M.; Dixon, D. J. Org. Lett. 2012, 14, 2492-2495. doi:10.1021/ol300779x

31. Massa, A.; Rizzo, P.; Monaco, G.; Zanasi, R. Tetrahedron Lett. 2013, 54, 6242-6246. doi:10.1016/j.tetlet.2013.09.020

32. Inokuma, Y.; Kwon, J. H.; Ahn, T. K.; Yoo, M.-C.; Kim, D.; Osuka, A. Angew. Chem., Int. Ed. 2006, 45, 961-964. doi:10.1002/anie.200503426

33. Edwards, L.; Gouterman, M.; Rose, C. B. J. Am. Chem. Soc. 1976, 98 , 7638-7641. doi:10.1021/ja00440a031

34. Akerman, M.; Cardozo, M.; Houze, J. B.; Li, A. R.; Liu, J.; Liu, J.; Ma, Z.; Medina, J. C.; Schmitt, M. J.; Sharma, R.; Sun, Y.; Wang, Y.; Wang, Z.; Zhu, L. Bicyclic carboxylic acid derivatives useful for treating metabolic disorders. WO Patent Appl. WO2007106469, Dec 21, 2007. 
35. Rao, I. N.; Prabhakaran, E. N.; Das, S. K.; Iqbal, J. J. Org. Chem. 2003, 68, 4079-4082. doi:10.1021/j0020559c

36. Petronzi, C.; Collarile, S.; Croce, G.; Filosa, R.; De Caprariis, P.; Peduto, A.; Palombi, L.; Intintoli, V.; Di Mola, A.; Massa, A.

Eur. J. Org. Chem. 2012, 5357-5365. doi:10.1002/ejoc.201200678

37. Krapcho, A. P.; Weimaster, J. F.; Eldridge, J. M.; Jahngen, E. G. E., Jr.; Lovey, A. J.; Stephens, W. P. J. Org. Chem. 1978, 43, 138-147. doi:10.1021/jo00395a032

38. Lafrance, D.; Bowles, P.; Leeman, K.; Rafka, R. Org. Lett. 2011, 13, 2322-2325. doi:10.1021/ol200575c

39. Allin, S. M.; Northfield, C. J.; Page, M. J.; Slawin, A. Z. M. J. Chem. Soc., Perkin Trans. 1 2000, 1715-1721. doi:10.1039/B001569P

40. Klapars, A.; Huang, X.; Buchwald, S. L. J. Am. Chem. Soc. 2002, 124, 7421-7428. doi:10.1021/ja0260465

\section{License and Terms}

This is an Open Access article under the terms of the Creative Commons Attribution License (http://creativecommons.org/licenses/by/2.0), which permits unrestricted use, distribution, and reproduction in any medium, provided the original work is properly cited.

The license is subject to the Beilstein Journal of Organic Chemistry terms and conditions:

(http://www.beilstein-journals.org/bjoc)

The definitive version of this article is the electronic one which can be found at: doi:10.3762/bjoc. 11.279 